\title{
Determinants of Organisational Commitment Among Generation -Y in the Malaysian SMEs
}

\author{
Jaya Ganesan ${ }^{1}$, Lee Kar Mun ${ }^{1} \&$ Kavitha Raman ${ }^{1}$ \\ ${ }^{1}$ Faculty of Business, Multimedia University, Jalan Ayer Keroh Lama,75450, Malacca, Malaysia. \\ Correspondence: Jaya Ganesan, Faculty of Business, Multimedia University, Jalan Ayer Keroh Lama,75450, \\ Malacca, Malaysia. Tel: 606-2523768. E-mail: jaya.ganesan@mmu.edu.my
}

Received: October 28, 2017

Accepted: November 8, 2017 Online Published: November 21, 2017

doi:10.5539/mas.v11n12p48

URL: https://doi.org/10.5539/mas.v11n12p48

\begin{abstract}
It is evident from research that Generation-Y constitutes a large proportion in the work force across the globe and hence it is a great challenge to organisations to attract and retain their Gen-Y employees. Various studies have highlighted that the knowledge of organisational commitment is crucial to organisations in developing their longterm performance and growth. This study aims to explore the determinants of organisational commitment among the Generation-Y who are employed in Malaysian SMEs (Johor Bahru, Selangor and Kuala Lumpur). The data was collected from 200 Gen-Y employees. Variables such as pay and benefits, training, leadership style, organisational culture and job satisfaction using multiple regression revealed that all variables had significant relationship with organisational commitment. Theoretical and practical implications are discussed based on the findings. The study also highlighted recommendations for future research.
\end{abstract}

Keywords: Organisational Commitment, Gen-Y, SMEs, Malaysia

\section{Introduction}

According to Kong (2015) Gen-Y will occupy $75 \%$ of the global workforce by the year 2025. Similarly, in the Malaysian context it is evident that the total population of Gen-Y is approximately 15 million (Figure1, Department of Statistics, Malaysia 2016). In other words, Gen-Y progressively make up a larger proportion of the workforce in Malaysia (Lau,2015). Thus, the study has identified a need to explore the determinants of organisational commitment among Gen-Yemployees in the SMEs since the commitment and contribution of employees are crucial for the growth of SMEs as well as their contribution to the nation's economy. Organisational commitment refers to the bond between employees and their organisation, which implies that the employees who fit in their positions, clearly understand their roles and responsibilities, and therefore able to assist the organisation to accomplish its goals (Werf, 2014). Besides, it can also be defined as an individual's sense of belonging towards organisation and willingness to remain in the organisation (Recep, Mahmut, Murat, 2010; Fornes and Rocco, 2014).

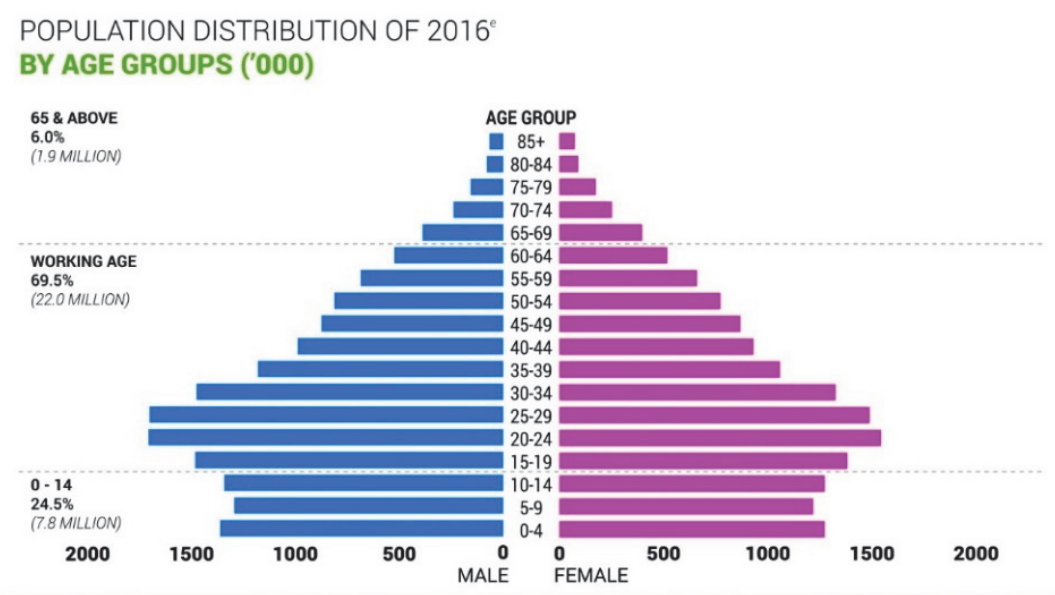

Figure 1. Population Distribution by Age Groups (000) Source: Department of Statistics, Malaysia 2016 
Figure 2 below indicates the statistics made by the U.S. Census Bureau, which highlights that by year 2025 , Generation Y and its successors will comprise more than half of the global population and $75 \%$ of the workforce (Bovis, Cardoso, Wright \& Gott, n.d.). In addition to this, Dr Karie Willyerd, the co-author of the 2020 Workforce - How Innovative Companies Attract, Develop and Keep Tomorrow's Employees Today, shares that by 2015, over $50 \%$ of the workforce in Malaysia will comprise of Generation Y workers ("Meet the needs," 2012) as cited in $\operatorname{Lim}(2014)$.
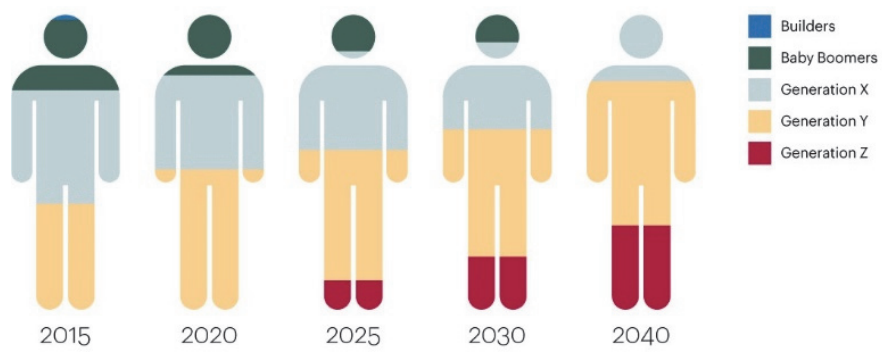

Figure 2. Generation $\mathrm{Y}$ in the Global Workforce

\subsection{Definition of SME}

The definition of SME (Figure 3) was revised in the year 2013 and was endorsed by the National SME Development Council (NSDC). According to this definition, the SMEs include all sectors such as agriculture, construction, manufacturing, mining and quarrying and services. The two main criteria that determines the definition are the sales turnover and the total number of full time employees employed by the SMEs.

For instance, in the case of manufacturing sector the SMEs are firms that are expected to achieve a maximum sales turnover not exceeding RM 50 million and such SMEs expected to have at least 20 full time employees. Similarly, in the case of services and all other sectors the definition of SME includes firms with a sales turnover of about RM20 million and at least 75 full time employees (http://www.smecorp.gov.my).

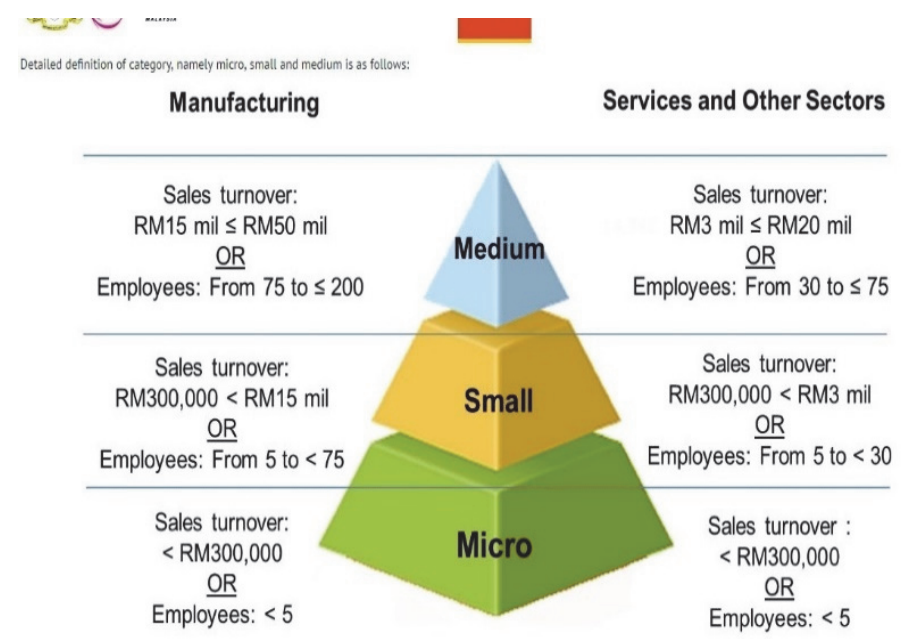

Figure 3. Definition of SME, Source: http://www.smecorp.gov.my

In Malaysia,98.5\% of the business establishments are SMEs and they are the backbone of the nation's economy. The study has selected SMEs since it is one of the major sectors in Malaysia that contributed around 36.65 to GDP ,18.6\% to exports and offered $65.3 \%$ employment opportunities in the year 2016 (Figure 4). Thus, the study has identified a need to explore the determinants of organisational commitment among Gen-Y in the SMEs since the commitment and contribution of the employees are crucial for the growth of SMEs as well as their contribution to the nation's economy. 


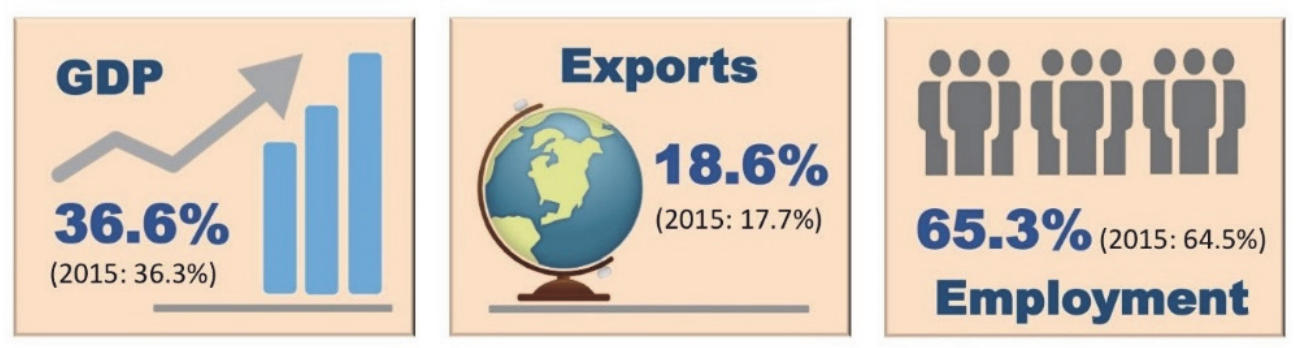

Source: Department of Statistics Malaysia (DOSM)

Figure 4. Contribution of SMEs in the year 2016, Source: http://www.smecorp.gov.my

\subsection{Problem Statement}

Organisational commitment among employees is a vital issue all around the world. Thus, lack of organisational commitment could lead to severe impact toward organization, especially the bottom line. This is supported by Osa and Amos (2014) as the authors pointed out that low organisational commitment could lead to workforce turnover, poor quality of work, and absenteeism. All of these issues incur a cost toward the organization. Thus, a study is needed to identify the factors affecting organization commitment. Besides, as Gen-Y is continuously entering the workforce, they will soon become the key contributors to the global workforce. However, research has highlighted that employers always claim that they are facing challenges in managing Gen-Y due to their unique individual characteristics (Gurchiek, 2009). Hence, it is vital to figure out the factors in building organisational commitment among Gen $-Y$ that directly affects their career advancement as well as the organisational profitability. Moreover, it is relatively common that there would be difference between employees' expectations and organisations' offers. This not only affects the employment relationship but also the psychological contract (Turnley, et al, 2003). Thus, the expectation gap emerges and directly influences the decision of both parties in recruitment and turnover. Therefore, this study aims to determine the relationship between organisational commitment and pay and benefits, training, job satisfaction, organisational culture and leadership style in the Malaysian SMEs.

\section{Literature Review}

Generation -Y, also known as Millennials, refers to individuals born between year 1980 and 2000 (Waterworth, 2013; Lynos (2016). The characteristics of Gen-Y are described by various authors such as Comeau et al., (2013) who stated that Generation -Y employees usually lack loyalty and frequently quit their careers. The most crucial element that affects Gen-Y is the growth of technology which determines their work methods, pace of innovation and creativity (Gursoy, Maier \& Chi, 2008; Cennamo et al., 2008; Shaw et al., 2008; Lim,2014). Most Gen-Y employees are highly capable of performing multitasking (Gursoy et al., 2008), however, they demand a high degree of work life balance (Broadridge, Maxwell \& Ogden, 2007).

Allen and Meyer (1990) had proposed a model of organisational commitment that included three elements. The first element is the affective component, which refers to the employees' emotional attachment to, identification with, and involvement with the organization. Next, is the continuance component, which refers to the perception of cost related decision to leave the organization. Finally, the normative component, which defines the employees' sense of obligation to stay in the organization. Organisational commitment is a vital tool to predict employees' attitude to the organization and it also assist orgnaisations in understanding and forecasting employees'turnover, withdrawal tendency and organisational citizenship behavior (Sinclair and Wright, 2005; Ghosh and Swamy ,2014).

According to Ghosh and Swamy (2014) "Organisational commitment is multi-faceted and hence needs to take into cognizance the organization and also an individual's perspective. Since commitment has both attitudinal and behavioural implications, it is paramount to come out with a proposition which tries to delve deeper into the psyche of individuals and their interactions with their organisation."

Pay and benefits includes any direct and indirect financial payment to the employee according to the employment agreement; while it also includes benefits, which is referred to the non-financial form to the base salary with the purpose to enhance an employee's quality of life (Nazir, 2010). This is supported by Heathfield (2016) who shared the similar point of view and state that compensation and benefit are both monetary and non-monetary items provided by the employers to their employees in exchange for their services. In other words, it can be also regarded as a reward by the organisation in order to recognise worker's contribution and performance (Huynh, 2012). Pay 
and benefits is one of the important factor that affect organization commitment, as it directly or indirectly affects employees' attitude towards work (Anvari, Amin, Ahmah, Seliman, \& Garmsari, 2011).

Chand (2016) and Armstrong (2001) defined training as activities of learning and teaching with the main objective of strengthening an employee's skills, knowledge, and capabilities required to perform a particular job. Biech (2015), further explained that training is a transformation process, which requires employees to change, in order to acquire new skill, latest knowledge and positive attitude. Aziri (2011) defined job satisfaction "as a combination of internal and external factors that results in satisfaction among employees in terms of their roles and responsibilities at work. Whereas Molla (2015) described job satisfaction as a set of positive and negative attitude associated with the employee's work behaviour. Taub (2015) indicated that job satisfaction represents the enjoyment that employees perceive the most in their position, roles, and responsibilities.

Organisational culture refers to the philosophy, belief, attitude, practices and behaviour that defines an organization (Rick, 2015). Similarly, Sun (2008) stated that organisational culture is the combination of values and beliefs that make up a unique social and psychological internal environment within an organization. Steen (2010) shared a similar viewpoint and described organisational culture as a "glue" which connect the people in the organization with the shared values and beliefs. In a simple term, organisational culture refers to the ways how employees perform their work (Martin, 2006). Helmrich (2016) define leadership as the ability or power to influences others. This is agreed by Taylor (2016), who stated that leadership is the ability to gild people towards the right direction with effective management skills. Huynh (2015) stated that leadership is an individual behaviour that directs a group of employees toward the same goal. Kruse (2013) make a clear-cut explanation that leader is someone who has voluntary followers.

\section{Research Methodology}

The study adopted a quantitative research methodology due to its nature and objective. The main purpose of this study is to determine the relationship between organisational commitment of Gen-Y employees (dependent variable) and Pay and benefits, job satisfaction, organisational culture, training and leadership style (independent variables). Data for the study was collected using a self-administered questionnaire. The development of the questionnaire was based on four previous studies by Huynh (2015), Newman, Thanacoody, Hui (2014), Alvi et al., (2014), and Griffith (2013). 200 Gen-Y employees working in various sectors from the regions of Johor Bahru, Selangor and Kuala Lumpur were involved in this study since these areas have the maximum number of SMEs. Figure 5 below indicates the overview of SMEs in Malaysia by state. The study used non-probability technique since the elements of the populations do not have any specific chance or a reason to be selected (Sekaran and Bougie, 2013). Convenience sampling was adopted since it is easier and efficient way to gather responses.

\section{Overview of SMEs in Malaysia by state}

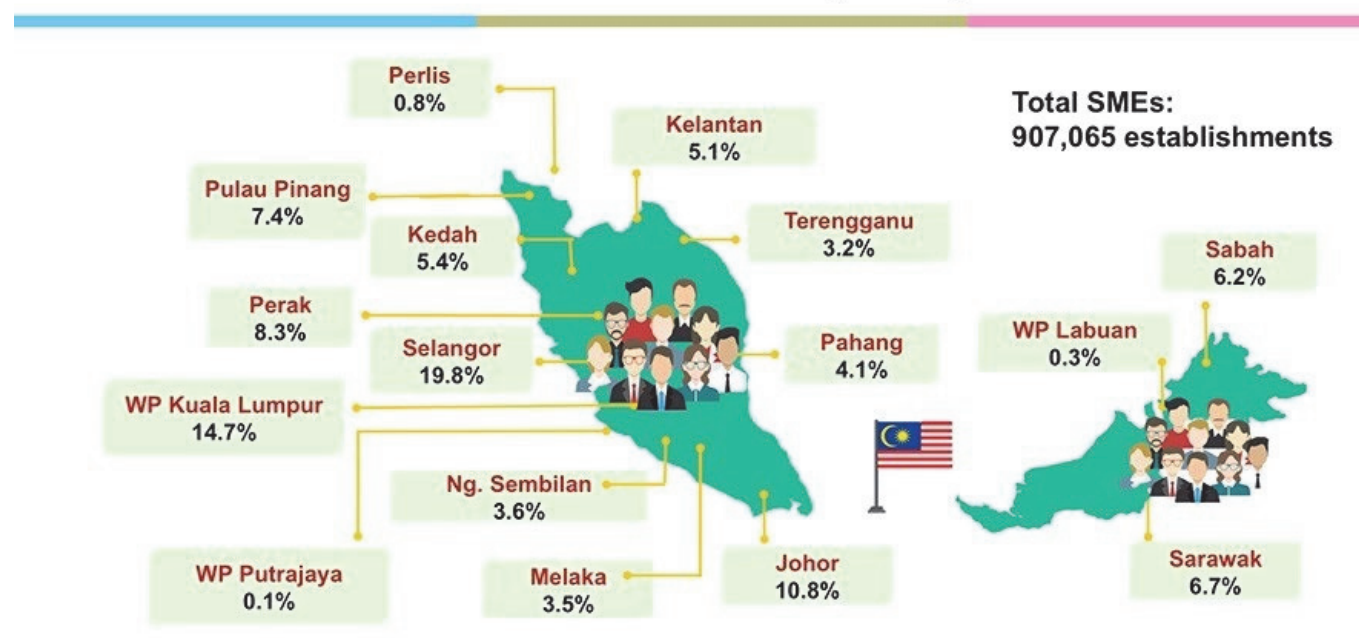

Source: Economic Census 2016, Department of Statistics Malaysia (DOSM)

Figure 5. Overview of SMEs in Malaysia by State. Source: Economic Census 2016, Department of Statistics Malaysia (http://www.smecorp.gov.my) 


\section{Results and Discussion}

The total response collected was 200 . All the questions were tested to be reliable and valid. The reliability value was all above 0.70 . The respondents are mainly from the age group of $25-29$ years $(70 \%)$, while those in the age group of between $20-24$ is around $20 \%$. Those between the age group of $30-34$ is around $10 \%$. Around $50 \%$ of the respondents are female. In terms of race distribution, majority of them are Chinese (45.5\%), followed by Malays (30.5\%), Indians (21\%) and others (3\%). Most of the respondents are educated at degree level (58\%), followed by diploma (26.5\%), postgraduate (4\%) and SPM (8. 5\%).In terms of pay most of the respondents earned a monthly salary between RM3000-3999 (48\%), followed by RM2000-2999 (38.5\%), RM1000-1999 (7.5\%) and some exceeded RM4000 (6\%)

Next the correlation analysis was conducted to test the relationship between the factors (pay and benefits, job satisfaction, organisational culture, training and leadership style) and organisational commitment. The result is presented in Table 1 . The highest correlation value is for leadership style $(\mathrm{r}=0.881)$, followed by the organisational culture $(r=0.863)$, pay and benefits $(r=0.861)$ and training $(r=0.847)$. The lowest value is the job satisfaction, $(r=$ 0.803 ). All of the five independent variables have positive relationship with organisational commitment at 0.000 significance level. Therefore, this means that pay and benefits, training, organisational culture, job satisfaction and leadership style have a significant relationship with organisational commitment.

Table 1. Results of Correlation Analysis

\begin{tabular}{lcl}
\hline & r & sig \\
\hline Pay and Benefits (PA) & $0.861^{* *}$ & 0.000 \\
Training (TN) & $0.847^{* *}$ & 0.000 \\
Job Satisfaction (JS) & $0.803^{* *}$ & 0.000 \\
Organisational Culture (OCU) & $0.863^{* *}$ & 0.000 \\
Leadership Style(LS) & $0.881^{* *}$ & 0.000 \\
\hline
\end{tabular}

Next, multiple regression analysis is done to identify the predictors of organisational commitment. Table 2 presents the multiple regression analysis results. The $r$ square value is 0.937 which indicates that $93.7 \%$ of the variation within the dependent variable is explainable by the variation in the five independent variables. Furthermore, the $F$ value is 279.499 and the $p$ value is $0.000(p<0.05)$ Therefore, it means that at least one of the independent variables predicts the dependent variable. The coefficient analysis result is presented in Table 3 . The significant value showed that all of the factors have $p$ value of below 0.05 . This means that all the factors are predictors. The highest beta value is for leadership style $(\mathrm{B}=0.357)$. This indicates that leadership style is the most significant influential factor on organisational commitment of Generation $-Y$. This is followed by organisational culture $(B=0.234)$, training $(B=0.220)$, pay and benefits $(B=0.201)$ and the lowest is for job satisfaction $(B=0.120 ; p<0.05)$.

Five factors were tested to identify which contributes to the organisational commitment of Gen-Y and the finding reveals all the factors tested are contributors. Pay and benefits is important to employees especially Gen-Y since they are more competent, innovative and creative. Most Gen-Y are highly capable of performing multitasking; hence they look for jobs that are highly challenging and impressive. They demand for competitive pay and benefits, attractive benefits, flexible working hours, high degree of work life balance, career advancement; hence they switch jobs frequently. Organisations must have effective human resource strategies to attract and retain these Gen$\mathrm{Y}$ employees. Hence, pay and benefits is found to contribute to organisational commitment. This finding is supported by Adeniji \& Osibanjo (2012), Lumley, E., et al. (2011), Huynh (2015) and Ju et al., (2008).

Table 2. Multiple Regression Analysis

\begin{tabular}{rrrcc}
\hline R & R Square & Std. Error of the Estimate & f & sig \\
\hline $.937^{\mathrm{a}}$ & .878 & .26594 & 279.499 & 0.000 \\
\hline
\end{tabular}


Table 3. Coefficient Table

\begin{tabular}{llllll}
\hline & \multicolumn{2}{l}{ Standard Coefficients } & Std Coefficient & $\mathrm{t}$ & $\mathrm{Sig}$ \\
\hline & $\mathrm{B}$ & Std Error & Beta & -5.629 & 0.000 \\
Constant & -.704 & .125 & & & \\
PA & .231 & .050 & .201 & 4.102 & 0.000 \\
TN & .244 & .059 & .220 & 4.162 & 0.000 \\
JS & .157 & .057 & .120 & 2.740 & 0.000 \\
OCU & .292 & .063 & .234 & 4.633 & 0.000 \\
LS & .416 & .059 & .357 & 7.020 & 0.000 \\
\hline
\end{tabular}

Model equation of the study $\mathrm{Y}=-704+.231 \mathrm{PA}+.244 \mathrm{TN}+.157 \mathrm{JS}+.292 \mathrm{OCU}+.416 \mathrm{LS}+\mathrm{ERROR}$.

Training is also found to contribute to the organisational commitment of Generation -Y. This finding is supported by Hurtz \& Williams (2009), Kraimer et al., (2011), Kim (2012). The availability of continuous training, motivation to learn, training environment and the potential benefits of training are all considered to be significantly relevant to improve organisational commitment among Gen-Ys. Moreover, training influences attitude towards work and also assist in enhancing job performance and skill development (Wood and De Menezes, 1998, Chew and Chan, 2007). Therefore, employers who are so desirous of enhancing organisational commitment among their Gen-Y employees should pay more attention to training. Training enhances specific job skills and helps accomplish specific goals. Thus, training is positively associated with organsational commitment. This is supported by previous studies such as (Ansari et al, 2000; Bashir and Choi,2015; Bulut and Culha, 2010). Next, job satisfaction is also influencing organisational commitment. This is because job satisfaction is the vital element to be committed with one's job and organisation. This is supported by (Benkhoff, 1997; Aranya, Kushnir \&Valency, 1986, Pearce, 2010; Kreitner \& Kinicki, 2006; Lumley, 2010). Similarly, job satisfaction is highly associated with developing a positive attitude towards organisational commitment (Clugston, 2000; Salim, Kamarudin and Kadir 2012; Gunlu, Aksarayli and Percin ,2010).

Next, organisational culture is also influencing organisational commitment. When organisations provide opportunities for continuous and desirable job outcomes to employees it leads to a positive organisational commitment. When organisations provide opportunities for team work, sharing similar values and beliefs employees develop a strong bond or fit with the orgnaisations. Similarly, when organisations set realistic and challenging targets to achieve with the presence of positive climate, employees tend to be loyal and productive. This is supported by (Acar, 2012; Nasr, 2015; Meyer et al., 2012). Finally, leadership style is found to be a contributive factor to organisational commitment. A leadership approach which inculcates continuous and positive changes at work place induces positive approach towards organisational commitment. This is supported by Özşahin et al., (2013). Leadership style influences employees'performance, employee engagement and interpersonal relationship at work place. It plays a key role in accomplishing organisational goals as well as personal goals. Employees tend to be more committed when they are appreciated and rewarded by their leaders and superiors. Leadership also attracts commitment through cooperation, empowerment and team work. This is supported by previous studies by Nordin (2012); Satyendra (2015); Prabu (2012); and Chand (2016).

\section{Conclusion}

The study has been able to satisfy the objective set which was to identify factors contributing to the organisational commitment among Gen-Y workers in the Malaysian SMEs. The overall findings suggest that the five factors such as pay and benefits, organisational culture, training, job satisfaction and leadership style contribute to organisational commitment among Gen -Y workers. The output derived from the study is able to add to the existing literature. From the employers'or organisations' perspective, organisational commitment is essential to ensure loyalty and performance. Organisational commitment will directly influence employees' decision to stay with the organization. Therefore, there is a need to strategise on pay and benefits, training and also to provide a healthy organisational culture. The study's main limitation was the sample size. Future study should consider using a much larger sample size. Nonetheless, Generation - X workers can be used as a comparative study sample. Organisations' viewpoint can also be an area of future study especially in terms of organisational commitment and challenges faced by SMEs. In addition, future study may consider an inclusion of additional variables to the existing ones studied here.

\section{Acknowledgement}

Department of Statistics, Malaysia. http://www.atkearney.com http://www.smecorp.gov.my 


\section{References}

Acar, A. Z. (2012). Organisational Culture, Leadership Styles and Organisational Commitment in Turkish Logistics Industry. Social and Behavioral Sciences, 58(12), 217- 226.

Adeniji, A. A., \& Osibanjo, A. O. (2012). Human Resource Management: Theory and Practice. Lagos. Pumark Nigeria Limited.

Alvi, H. A., Hanif, M., Adil, M. S., Ahmed, R. R., \& Vveinhdardt, J. (2014). Impact of Organisational Culture on Organisational Commitment and Job Satisfaction. European Journal of Business and Management, 6(27), 30-39.

Ansari, M. A., Hung, D. K. M., \& Aafaqi, R. (2000). Fairness of Human Resource Management Practices, LeaderMember Exchange, and Intention to Quit. Journal of International Business and Entrepreneurship, 8(1), 119.

Anvari, A., Ahmin, S. M., Ahmad, U. N. U., Seliman, S., \& Garmsari, M. (2011). The Relationship Between Strategic Compensation Practice and Affective Organisational Commitment. Interdisciplinary Journal of Research in Business, 1, 44-55.

Armstrong, M. (2001). A Handbook of Human Resource Management Practice, 8th ed., Kogan Page Publisher, London.

Aziri, B. (2011). Job Satisfaction: A Literature Review. Management Research and Practice, 3, 77-86.

Bashir, N., \& Choi, S. L., (2015). The Relationship between Training and Organisational Commitment among Academician in Malaysia. Journal of Management and Development, 35, 1227-1245.

Biech, E. (2015). What is Training and Development. Human Resource Business Development. Retrieved September 7, 2016, from http://www.dummies.com/business/human-resources/employee-engagement/whatis-training-and-development/

Broadridge, A., Maxwell, G., Ogden, S. (2006). Retailing, Careers and Generation Y. Institute for Retail Studies Working Paper 0601.

Bulut, C., \& Culha, O. (2010). The Effect of Organisational Training on Organisational Commitment. International Journal of Training and Development, 14(4), 309-322.

Bump, P. (2014). Here Is When Each Generation Begins and Ends, According to Fact. The Atlantic. Retrieved September 2, 2016, from http://www.theatlantic.com/national/archive/2014/03/here-is-when-eachgeneration-begins-and-ends-according-to-facts/359589/

Cennamo, L., \& Gardner, D. (2008). Generational differences in work values, outcomes and person organisation values fit. Journal of Managerial Psychology, 23(8), 891-906. https://doi.org/10.1108/02683940810904385

Chand, S. (2016). Meaning, Definition and Type of Training. Your Article Library. Retrieved September 7, 2016, from http://www.yourarticlelibrary.com/human-resource-development/training-meaning-definition-andtypes-of-training/32374/

Chew, J., \& Chan, C. C. A. (2007). Human resource practices, organisational commitment and intention to stay. International Journal of Manpower, 29(6), 503-522.

Clugston, M. (2000). The mediating effects of multidimensional commitment on job satisfaction and intent to leave. Journal of Organisational Behaviour, 21(4), 477-486.

Department of Statistics Malaysia. (2016). Retrieved from https://www.statistics.gov.my

Fornes, S. L., Rocco, T. S., (2014). Commitment Elements Reframed (Antecedents \& Consequences) for Organisational Effectiveness, 391-398.

Gallato, C. G., Rashid, S., Suryasaputra, R., Warokka, A., Reamillo, K. A. G., \& Abdullah, H. H. B. (2012). Fostering Niche among SMEs in Malaysia through Organisational Commitment, Leadership, Organisational Culture and Job Satisfaction. Journal of Innovation Management in Small \& Medium Enterprise, 2012

Ghosh, S., \& Swamy, D. R. (2014). A Literature Review on Organisational Commitment: A Comprehensive Summary. International Journal of Engineering Research and Applications, 4(12, Part 1), 4-14.

Griffith - Kranenburg. (2013). The Effect of Organisational Culture and Leadership style on Organisational Commitment Within SMEs in Suriname, With Job Satisfaction as a Mediator, Unpublished Thesis, Maastricht School of Management 
Gunlu, E., Aksarayli, M., \& Percin, N. S. (2010). Job Satisfaction and Organisational Commitment of Hotel Manager in Turkey. International Journal of Contemporary Hospitality Management, 22, 693-717.

Gurchiek, K. (2009). Gen Y Poses Unique Management Challenges. Society For Human Resource Management Article. Retrieved 1 August. 2016, from https://www.shrm.org/ResourcesAndTools/hr-topics/employeerelations/Pages/GenYChallenges.aspx

Gursoy, D., Maier, T. A., \& Chi, Christina G. (2008). Generational differences: An examination of work values and generational gaps in the hospitality workforce. International Journal of Hospitality Management, 27, 448-458.

Heathfield, S. M. (2016). Compensation - Definition and Inclusion. The Balance. Retrieved September 6, 2016, from https://www.thebalance.com/compensation-definition-and-inclusions-1918085

Helmrich, B. (2016). Ways to Define Leadership. Business News Daily. Retrieved September 11, 2016, from http://www.businessnewsdaily.com/3647-leadership-definition.html

Hurtz, G. M., \& Williams, K. J. (2009). Attitudinal and motivational antecedents of participation in voluntary employee development activities. Journal of Applied Psychology, 94, 635-653.

Huynh, T. H. (2015). Factor Influencing Organisational Commitment and Intention to Stay of Core Employee. Journal of Applied Management and Entrepreneurship, 2012, 3(1).

Ju, S., Kong, L., Hussin, Z. H., \& Jusoff, K. (2008). The Influence of Employee Benefits Towards Organisational Commitment. Asian Social Science, 4, 147-150.

Kim, S. (2012). The impact of human resource management on state government IT employee turnover intentions. Public Personnel Management, 41, 257-279.

Kong, G. (2015). Malaysian Millennials shaking up the workplace. Businesscircle Journal. Retrieved August 1, 2016, from http://www.businesscircle.com.my/malaysian-millennials-shaking-up-the-workplace/

Kraimer, M. L., Seibert, S. E., Wayne, S. J., Liden, R. C., \& Bravo, J. (2011). Antecedents and outcomes of organisational support for development: The critical role of career opportunities. Journal of Applied Psychology, 96, 485-500. https://doi.org/10.1037/a0021452

Kreitner, O. B., \& Kinicki, G. K. (2006). Organisational Behaviour. New York. McGraw Hill.

Kurse, K. (2013). What is Leadership. Forbes. Retrieved September 11, 2016, from http://www.forbes.com/sites/kevinkruse/2013/04/09/what-is-leadership/\#2765aff9713e

Lau, L. (2015). Managing Baby Boomers, Gen-X, Gen-Y At Work. Leader economic Journal. Retrieved August 1, 2016, from http://leaderonomics.com/leadership/managing-baby-boomers-gen- $x$-and-gen-y-at-work

Lee, H. Y., \& Ahmad, K. Z. B. (2009). The Moderating Effects of Organisational Culture on the Relationship Between Leadership Behavior and Organisational Commitment. Leadership and Organization Development Journal, 30, 53-86.

Leech, N. L., Barrett, K. C., \& Morgan, G. A. (2007). SPSS for Intermediate Statics: Use and Interpretation. 3rd Edn., Routledge Academic, New Jersey, USA., ISBN-13: 978-0805862676, Pages: 58.

Lim, X. Y. (2014). Factors that Affect Generation Y Workers' Organisational Commitment, Unpublished thesis., UKM, Malaysia.

Lumley, E., et al. (2011). Exploring the job satisfaction and organisational commitment of employees in the information technology environment. Southern African Business Review, 15(1), 100-118.

Lyons, K. (2016). Generation-Y, A Guide to a Much-maligned Demographic Theguardian Article. Retrieved December 2016 from https://www.theguardian.com/world/2016/mar/07/millennials-generation-y-guide-tomuch-maligned-demographic

Mahmood, A. (2015). Effect of Leadership Style on Organisational Commitment in Public and Private Sector of Pakistan. Business and Management Studies, 3, 246-311.

Main, D. (2013). Who Are The Millenials. Live science Article. Retrieved Aug 1, 2016, from http://www.livescience.com/38061-millennials-generation-y.html

Martin, J. (2006). That's the Way We Do Things Around here: An Overview of Organisational Culture. Electronic Journal of Academic and Special Librarianship, 7(1).

Meyer, J. P., Stanley, D. J., Jackson, T. A., McInnis, K. J., Maltin, E. R., \& Sheppard, L. (2012). Affective, 
normative, and continuance commitment levels across cultures: A meta-analysis. Journal of Vocational Behavior, 80(2), 225-245.

Molla, M. I. H. (2015). Ensuring Job Satisfaction for Managing People at Work. Global Disclosure of Economic and Business, 4(2), 155-166.

Nasr, R. (2015). Harnessing Corporate Culture to Make Employee Loyal To Your Brain, Not Your Money. Entrepreneur Middle East. Retrieved September 10, 2016, from https://www.entrepreneur.com/article/246061

Nazir, N. (2010). Compensation and Benefit: Definition and Important. HR.Com. Retrieved Dec 2016, from http://www.hr.com/en/app/blog/2010/02/compensation-and-benefits-definition-andimportanc_g5kiosxm.html

Newman, A., Thanacoody, R., \& Hui, W. (2010). The impact of employee perceptions of training on organisational commitment and turnover intentions: A study of multinationals in the Chinese service sector.A. Nottingham University Business School, Ningbo China b. Middlesex University Business School.

Nordin, N. (2012). The Influence of Leadership Behavior and Organisational Commitment on Organisational Readiness for Change in a Higher Learning Institution. Asia Pacific Education Review, 13(2), 239-249.

Osa, I. G., \& Amos, I. O. (2014). The Impact of Organisational Commitment on Employee Productivity: A Case Study of Nigeria Brewery, PLC. International Journal of Research in Business Management, 2, 107-122.

Özşahin, M., Zehir, C., Acar A. Z., \& Sudak, M. K. (2013). The Effects of Leadership and Market Orientation on Organisational Commitment. Social and Behavioral Sciences, 99(6), 363-372.

Prabu, S. (2012). Important of Leadership Effectiveness. Training Zone. Retrieved Dec, 2016, from http://www.trainingzone.co.uk/community/blogs/sudhakarprabu/importance-of-leadership-effectiveness

Recep, B., Mahmut, D., \& Murat, D. (2010). Organisational Commitment and Case Study on the Union of Municipalities of Marmara. Regional and Sectoral Economic Studies, 10(2).

Rick, T. (2015). What is Organisational Culture. Meliorate. Retrieved September 10, 2016, from http://www.torbenrick.eu/blog/culture/organisational-culture/

Salim, M., Kamarudin, H., \& Kadir, M. B. A. (2012). Factor Affecting Organisational Commitment among Lecturer in Higher Education Institution in Malaysia. Social and Behavioral Science, 96, 2164-2173.

Satyendra, B. (2015). Important of Leadership for Organisational Excellent. Ispat Guru. Retrieved September 12, 2016, from http://ispatguru.com/importance-of-leadership-for-organisational-excellence/

Sekaran, U., \& Bougie, R. (2013) Research Methods for Business: A Skill-Building Approach. 6th Edition, Wiley, New York.

Siew, Y. K. (2015). Employee Retention Remains A Key Challenge in Malaysia, Claim supervisors face challenges in making time to perform their most important task. Wilies Towers Watson Journal. Retrieved https://www.towerswatson.com/en/Press/2015/01/Employee-Retention-Remains-A-Key-Challenge-inMalaysia

Steen, E. V. D. (2010). On the Origin of Shared Belief and Corporate Culture. RAND Journal of Economics, 41(4), 617-648.

Sun, S. L. (2008). Organisational Culture and Its Themes. International Journal of Business and Management, $3(12), 137-141$.

Taub, R. (2015). Your Five Step Method for Defining Job Satisfaction. Work It Daily. Retrieved September 7, 2016, from https://www.workitdaily.com/5step-method-defining-job-satisfaction/

Taylor, N. F. (2016). What Makes A Great Leader. Business News Daily. Retrieved September 11, 2016, from http://www.businessnewsdaily.com/2730-leadership.html

Turnley, W. H., Lester, S. W., Bloodgood, J. M., \& Bolino, M. C. (2003). Not Seeing Eye to eye: Differences in supervisor and subordinate perceptions of and attributions for psychological contract breach. Journal of Organisational Behavior, 23, 39-56.

Warsi, S., Fatimah, N., \& Sahibzada, S. A. (2009). Study on Relationship between Organisational Commitment and its Determinants among Private Sector Employees of Pakistan. International Review of Business Research Paper, 5(3), 399-410. 
Waterworth, N. (2013). Generation-X, Generation-Y, Generation-Z, and the Baby Boomers. Talented Heads. Retrieved Dec2016, from http:/www.talentedheads.com/2013/04/09/generation-confused/

Werf, R. V. D. (2014). Three Key Type of Organisational Commitment. Effectory International. Retrieved from https://www.effectory.com/thought-leadership/blog/3-key-types-of-organisational-committment/

Wood, S., \& De Menezes, L. (1998). High commitment management in the UK: evidence from the workplace industrial relations survey and employers' manpower and skills practices survey. Human Relations, 51, $415-$ 85 .

\section{Copyrights}

Copyright for this article is retained by the author(s), with first publication rights granted to the journal.

This is an open-access article distributed under the terms and conditions of the Creative Commons Attribution license (http://creativecommons.org/licenses/by/4.0/). 